\title{
EYES ON BANGLADESH'S DISAPPEARING COASTS: PROPOSED CONSTITUTIONAL PROTECTIONS FOR COASTAL COMMUNITIES PARTICULARLY VULNERABLE TO CLIMATE CHANGE ${ }^{1}$
}

\author{
Sabrina Persaud*
}

\begin{abstract}
Climate change, a phenomenon caused by global warming, has $\checkmark$ impacted just about every part of the earth. As polar ice caps continue to melt, people across the world are experiencing record-breaking heat waves and warmer winters. These erratic weather patterns are just one of the many impacts of climate change. Changes in temperature have altered ecosystems and habitats for terrestrial and marine wildlife, and caused human health to deteriorate. Larger, more industrialized countries are the major contributors to climate change; however, smaller countries, such as Bangladesh, suffer the consequences. This article analyses the negative effects that climate change has had on Bangladesh, particularly the vulnerable coastal communities of Bangladesh. Warmer temperatures lead to warmer waters, a breeding ground for tropical cyclones and spells disaster for those living along Bangladesh's coasts. This article proceeds to suggest possible domestic and international legal solutions to the problem and examines the law that supports these proposals.
\end{abstract}

Keywords: Climate change, coast, Bangladesh, constitution doi: http://dx.doi.org/10.4314/jsdlp.v6i1.3

* Juris Doctor (JD) Candidate, Florida Agricultural and Mechanical University (FAMU) Law School, United States.

1 "Eyes on Bangladesh's Disappearing Coasts" is a subtle reference to the eye of a tropical system that maintains contact with the Bangladeshi coasts and wreaks havoc for coastal communities. Every cyclone with wind speeds exceeding 74 $\mathrm{mph}$ has an eye at the centre of the storm, which is the calmest part of the storm. National Weather Service, “Tropical Cyclone Structure” <www.srh.noaa.gov/ jetstream/tropics/tc_structure.htm> accessed 28 July 2015. 


\section{INTRODUCTION}

A lhough Bangladesh is not a significant emitter of greenhouse gases - that contribute to climate change, the coastal country is suffering disproportionately from the effects of climate change. ${ }^{2}$ For each person living in Bangladesh, the country has an annual global carbon emission of 0.3 tonnes, which is marginal in comparison to other developing nations that have, on average, global carbon emissions of 1.6 to 2.0 tonnes. $^{3}$ Bangladesh's emissions are even more minuscule when compared to the United States, which emits about 20 tonnes of global carbon per capita, per year. ${ }^{4}$ These increased carbon emissions are the driving force behind the earth's change in climate and global warming. ${ }^{5}$ Despite their marginal contributions to climate change, South Asian nations such as Bangladesh, are particularly vulnerable to the potential impacts of climate change. ${ }^{6}$

In Bangladesh, the warming of the upper level of the ocean, which has resulted in increased ocean thermal energy, has been linked to climate change. ${ }^{7}$ This warming has equally been linked to intensified tropical cyclones. ${ }^{8}$ As a result of climate change, Bangladesh has witnessed more devastating tropical cyclones. ${ }^{9}$ These destructive storms will lead to larger storm surges, which will create more flooding and salt-water intrusion along the coasts. ${ }^{10}$ The storms will also destroy coastal properties,

2 United Nations, “Conference on Sustainable Development”, Rio de Janeiro, Brazil, 20-22 June 2012, Bangladesh Rio + 20: National Report on Sustainable Development (2012) <https://sustainabledevelopment.un.org/content/ documents/981 bangladesh.pdf $>$ accessed 28 July 2015; Sujatha Byravan, 'Climate Policy and the Poor: Some Perspectives' (2014) Environmental Justice 142, 143.

3 United Nations, ibid.

4 ibid.

5 Randall S. Abate and Sarah Ellen Krejci, "Climate Change Impacts on Ocean and Coastal Law: Scientific Realities and Legal Responses” in Randall S. Abate (ed), Climate Change Impacts on Ocean and Coastal Law: U.S. and International Perspectives (Oxford University Press, 2015).

6 Byravan (n2).

7 OTEC News, "What is OTEC" < www.otecnews.org/what-is-otec/> accessed 28 July 2015.

8 Abate (n4).

9 United Nations (n 2); Government of the People's Republic of Bangladesh, "Bangladesh Climate Change Strategy and Action Plan" (2008) <www.sdnbd.org/ moef.pdf $>$ accessed 29 July 2015; see also Anika Rahman, "Climate-Induced Migration: A Looming Crisis” (22 January 2015) <www.huffingtonpost.com/ anika-rahman/climateinduced-migration-_b_6497652.html> accessed 28 July 2015. 
agricultural land, and the livelihoods of many impoverished people. ${ }^{11}$ In 2007, tropical cyclone Sidr, a category 4 storm, made landfall on Bangladesh's southwest coast causing complete destruction of the primary residences of 34 per cent of the impacted households. ${ }^{12}$ In 2009, tropical cyclone Aila also hit Bangladesh's southwest coast and destroyed over 68,000 homes. ${ }^{13}$ The impacts of these cyclones are still seen today. ${ }^{14}$

Coastal communities are facing poverty, lack of economic opportunities, and displacement with no signs of improvement, thus making them more susceptible to climate change effects. ${ }^{15}$ But seeking a remedy to this problem under international law, such as the United Nations Framework Convention on Climate Change (UNFCCC) treaty regime, will not aid Bangladeshis in responding and adapting to climate change impacts. The climate change treaty regime focuses primarily on stabilizing greenhouse gas concentrations within the atmosphere ${ }^{16}-$ something to which Bangladesh has not significantly contributed. ${ }^{17}$ PostKyoto negotiations, such as the Green Climate Fund ${ }^{18}$ and the Warsaw International Mechanism on Loss and Damage, ${ }^{19}$ focus on climate change

10 Byravan (n2).

11 ibid.

12 Md. Shamsuddoha et al., "Local Perspective on Loss and Damage in the Context of Extreme Events: Insights from Cyclone-Affected Communities in Coastal Bangladesh" (2013) <www.lossanddamage.net/download/7105.pdf > accessed 29 July 2015.

13 ibid.

14 Islamic Relief Worldwide, “Real solutions needed for Bangladesh's cyclone affected communities" (5 June 2014) <www.islamic-relief.org/real-solutionsneeded-for-bangladeshs-cyclone-affected-communities-2/> accessed 28 July 2015. 15 ibid.

16 Int'l Bar Ass'n, “Achieving Justice and Human Rights in an Era of Climate Disruption” (2014) <www.ibanet.org/PresidentialTaskForceCCJHR2014.aspx> accessed 29 July 2015. (This report illustrates the causal connection between climate change and human rights and shows how climate change is an obstacle to the continued progress of human rights, thus contributing to and worsening the existing inequalities in the world.)

17 United Nations (n2).

18 The Green Climate Fund is a climate change fund that focuses on providing financing to developing countries, particularly those most vulnerable to the effects of climate change. Green Climate Fund, "Background" <www.gcfund.org/about/ the-fund.html> accessed 29 July 2015. The fund aims to help developing countries adapt to climate change; ibid. 
financing and damage assessments. ${ }^{20}$ These measures build on the Bali Action Plan, which proposed several adaptation measures like risk management and risk reduction strategies, incentives for countries that implement adaptation measures, and the idea that developed countries should provide financial support and technological assistance to developing countries. ${ }^{21}$ However, with developed countries being the biggest contributors to greenhouse gas emissions, ${ }^{22}$ these adaptation efforts will take many years to implement, and decades could elapse before any meaningful results are achieved. Therefore, in the interim, coastal populations must turn to international human rights laws and policies to seek reparations for the harms caused by global climate change.

Following the Introduction, section 2 of this paper discusses the impacts of climate change on coastal communities in Bangladesh. It examines how climate change has created much more intensified and devastating tropical cyclone activity within the Bay of Bengal and the destruction that the tropical cyclones have caused to Bangladesh's coasts. Section 3 analyses the existing national and international legal framework and discusses the duties of the Bangladeshi government to provide shelter to nationals. Internationally, the coastal communities of Bangladesh can

19 The Warsaw International Mechanism on Loss and Damage came out of the UNFCCC Conference of Parties held in Warsaw, Poland in 2013. United Nations Framework Convention on Climate Change, "Warsaw International Mechanism for Loss and Damage associated with Climate Change Impacts" <http:// unfccc.int/adaptation/workstreams/loss_and_damage/items/8134.php > accessed 29 July 2015. The Loss and Damage Mechanism addresses "Implementation of approaches to address loss and damage associated with the adverse effects of climate change" ibid.

20 See generally Conference of the Parties to the Sixteenth Session of the United Nations Framework Convention on Climate Change, Cancun, Mex., Nov. 2910 December 2010, Report of the Conference of the Parties: Decisions Adopted by the Parties, 17, U.N. Doc. FCCC/CP/2010/7/Add.1 (Mar. 15, 2011), available at <http://unfccc.int/resource/docs/2010/cop16/eng/07a01.pdf\#page=17>; Conference of the Parties to the Nineteenth Session of the United Nations Framework Convention on Climate Change, Warsaw, Pol., Nov. 11-23, 2013, Report of the Conference of the Parties: Decisions Adopted by the Parties, 6-8, UN Doc. FCCC/CP/2013/10/Add.1 (31 Jan. 2014), available at <http:// unfccc.int/resource/docs/2013/cop19/eng/10a01.pdf > [hereinafter WIM Loss and Damage].

21 See ibid.; see also Travis Thompson, "Getting Over the Hump: Establishing a Right to Environmental Protection for Indigenous Peoples in the Inter-American Human Rights System” (2009) 19 Journal of Transnat'l L. E Pol'y 179, 203.

22 United Nations (n2). 
seek remedies under international human rights treaties that discuss the adequate standard of living.

Section 4 offers three solutions to this growing crisis. First, it proposes that the opportunity to purchase flood insurance is a constitutional right for all Bangladeshis, including those living along the coasts; particularly, those impoverished coastal families who lack such insurance coverage and are deprived of the opportunity to purchase insurance coverage. While flood insurance is currently offered in different parts of Bangladesh, it is not offered to families living along the coasts, which are most heavily impacted by tropical cyclones. Second, the national climate change trust fund needs to be restored to fund projects to build proper infrastructure, such as paved roadways and bigger shelters, to assist families in moving out of harm's way. The money from the national fund should also be used to build homes for coastal families who have been displaced because of the tropical cyclone activity. Finally, better enforcement of international socio-economic human rights, such as the right to food and adequate shelter, is needed. Section 5 concludes the paper.

\section{INCREASED WATER TEMPERATURES STIR TROUBLE FOR THE COASTS OF BANGLADESH}

\subsection{Bangladesh’s Geographic Makeup and Coastal Life}

The geographic location of Bangladesh, along with its topographical features, has made the country one of the most vulnerable nations to climate change. ${ }^{23}$ Bangladesh is a relatively small South Asian nation that is situated just north of the Bay of Bengal and south of the Himalayas. ${ }^{24}$ The country is located within the Bengal Basin, which is "one of the largest geosynclin[es $]^{25}$ in the world." ${ }^{26}$ About 80 per cent of the country

23 Anwar Ali, "Climate change impacts and adaptation assessment in Bangladesh" (27 August 1999) <www.int-res.com/articles/cr/12_2/c012p109.pdf> accessed 29 July 2015.

24 ibid.

25 Geosynclinal is an adjective used to describe a geosyncline, which is long, "basinlike depression along the edge of a continent, in which a thick sequence of sediments and volcanic deposits has accumulated." The Free Dictionary, "Geosynclinal” <www.thefreedictionary.com/Geosynclinal> accessed 30 July 2015.

26 "Overview" <www.rrcap.ait.asia/pub/soe/bangladesh_part2.pdf> accessed 30 July 2015. 
is made up of floodplains; ${ }^{27}$ thus many parts of the country lie just less than 12 metres above sea level. ${ }^{28}$ It has been predicted that a mere onemetre rise in sea level will flood thousands of square kilometres of land. ${ }^{29}$ The climate of Bangladesh involves high temperatures, heavy rainfall, and high humidity. ${ }^{30}$

The world's largest river delta, comprised of the Ganges, Brahmaputra, and Meghna rivers, lies within the borders of Bangladesh and empties into the Bay of Bengal. ${ }^{31}$ This river delta consists of about 700 rivers, canals, and streams, and spans a length of over 22,000 kilometres. ${ }^{32}$ Thus, there is an immense amount of water flowing through the borders of Bangladesh, with approximately 870 million acre-feet of water flowing into the country from India. ${ }^{33}$ Natural resources for the country are derived from the river delta, and the livelihoods of many Bangladeshis revolve around the riverbeds. ${ }^{34}$

The country is home to approximately 160 million people, ${ }^{35}$ and about two thirds of the population works in agricultural based industries. ${ }^{36}$ Although many people work as farmers and have a source of income, 76 per cent of the population lives on less than two dollars a day. ${ }^{37}$ About 45 million people, or one-third of the total population of Bangladesh, lives below the poverty line, and a large number of those people live in extreme

27 Anne-Katrien Denissen, “Climate Change \& its Impacts on Bangladesh" (4 March 2012) <www.ncdo.nl/artikel/climate-change-its-impacts-bangladesh $>$ accessed 30 July 2015.

28 Embassy of Bangladesh, "Geography \& Climate" <www.bdembassyusa.org/ index.php?page=geography $>$ accessed 30 July 2015.

29 Claire DeWitte, “At The Water's Edge: Legal Protections and Funding for a New Generation of Climate Change Refugees" (2010) 16 Ocean E Coastal L. J., 211, 215-16; see also Embassy of Bangladesh (n28).

30 Denissen (n27).

31 DeWitte (n29); see also Embassy of Bangladesh (n28).

33 Overview (n26).

33 M.A. Abedin et al., "Health: Impacts of Salinity, Arsenic and Drought in Southwestern Bangladesh", in Rajib Shaw and Phong Trans (eds), Environment Disaster Linkages (Emerald Group Publishing, 2012).

34 DeWitte (n29).

35 ibid.

36 Denissen, (n27).

37 OxfaminBangladesh, "Index Based Flood Insurance - First Payout - October 2014" (Youtube video) (24 December 2014) <www.youtube.com/watch?v=ZKQa 4H3eOTO> accessed 12 July 2015. 
poverty. ${ }^{38}$ Extreme poverty has been defined by the United Nations as more than just a lack of sufficient income. ${ }^{39}$ Those living in extreme poverty are deprived of access to basic services such as education, healthcare, safe drinking water, and basic sanitation..$^{40}$ They are also subject to social exclusion and are often unable to participate in the political process or seek justice for themselves. ${ }^{41}$

Approximately one-fourth of the total population lives along the coasts of Bangladesh, ${ }^{42}$ which is a poverty-stricken area. ${ }^{43}$ Thus, because of their poor economic status, vulnerable coastal families in Bangladesh may be deprived of basic necessities and economic and social opportunities. ${ }^{44}$ These families are similar to the favelados ${ }^{45}$ of Brazil, who are marginalized and "socially and legally disconnected from the larger society." ${ }^{46}$ Many people living in these favelas ${ }^{47}$ are impoverished and when a natural disaster occurs, "the formal avenues to reconstruct their homes and communities are not sufficient." 48 These communities are already deprived of basic necessities such as water, electricity, and sanitation services, ${ }^{49}$ which could also be the looming climax for Bangladesh's impoverished coastal families affected by more destructive tropical cyclones.

38 Rural Poverty Portal, "Rural poverty in Bangladesh" <www.ruralpovertyportal. org/country/home/tags/Bangladesh> accessed 30 July 2015.

39 United Nations Human Rights, "Special Rapporteur on extreme poverty and human rights" <www.ohchr.org/EN/Issues/Poverty/Pages/SRExtremePoverty Index.aspx> accessed 30 July 2015.

40 ibid.

41 ibid.

42 Denissen (n27).

43 Rural Poverty Portal (n38).

44 United Nations Human Rights (n39).

45 A favelado is "a person who lives in a favela." Dictionary.com, "Favelado" < http:/ /dictionary.reference.com/browse/favelado> accessed 30 July 2015.

46 Cherice Fleming Togun, "Waters that Bridged the Social Gap: Indigenous Population Protections for Displaced Favela Residents in Brazil” (2012) (unpublished manuscript, Fla. A \& M Univ. Coll. of Law) (on file with author); see also Juliana Britto Schwartz, “Rio De Janeiro has Started 'Legalizing' Favela Residents” <http://feministing.com/2014/01/03/rio-de-janeiro-has-startedlegalizing-favela-residents/> accessed 30 July 2015.

47 Favelas are shanty-towns in Brazil that often lack basic necessities and public investment. Julia Carneiro, “Favela life: Rio’s city within a city” (9 June 2014) <www.bbc.com/news/world-latin-america-27635554> accessed 30 July 2015.

48 Togun (n46).

49 See ibid 5. 


\subsection{Tropical Cyclones Engulf the People and Homes at Bangladesh's Coasts}

The Bay of Bengal is viewed as the breeding ground for a large number of catastrophic cyclones. ${ }^{50}$ As excess carbon dioxide is released into the atmosphere, a greenhouse effect ${ }^{51}$ is created, which then causes a "planetwide warming trend," leading to warmer waters. ${ }^{52}$ Bangladesh already has a long history of enduring deadly tropical cyclones that emerge from the Bay of Bengal,,$^{53}$ but due to the increased water temperatures that have resulted from climate change, the nation's inhabitants will witness more severe tropical cyclones. ${ }^{54}$

This disaster-prone country is subject to a large number of damages to life and property each year because of the increase in natural disasters. ${ }^{55}$ As a result of tropical cyclone activity, Bangladeshis experience a loss of agricultural production, disruption of communication and livelihood systems, damage and destruction of immobile infrastructure, injury, and the loss of biodiversity and human lives. ${ }^{56}$ The country itself suffers national economic loss. ${ }^{57}$ As storm surges, brought about by tropical cyclones, make their way inland, it has been estimated that about 17 million Bangladeshis could lose their homes and become displaced from the flooding caused by cyclones. ${ }^{58}$ Farmers living along the coasts are also at risk of losing their land, meaning they would lose their livelihood

50 ___-_, “Natural Disasters” <www.rrcap.ait.asia/pub/soe/bangladesh_ disasters.pdf $>$ accessed 30 July 2015.

51 "The greenhouse effect refers to a natural condition created when certain gases, primarily carbon dioxide, mix with water vapor and create an atmospheric greenhouse that traps solar heat between it and the surface of the planet." Jose L. Fernandez, "Global Warming Legislation: Putting the Carbon Genie Back in the Bottle” (1991) 42 Syracuse L. Rev. 1095, 1097.

52 Lecture on Climate Change Impacts on Ocean and Coastal Law by Dr. Sarah Ellen Krejci (21 January 2015).

53 Chris Dolce, "The Storm that Killed 300,000" (25 April 2014) $<$ www.weather.com/storms/hurricane/news/deadliest-cyclone-historybangladesh-20130605\#/1> accessed 30 July 2015.

54 Rahman (n9); see also Dr. Sarah Ellen Krejci (n52).

55 Natural Disasters (n 0 ).

56 ibid., see also Denissen ( $\mathrm{n} 7)$.

57 ibid.

58 Ross C. "Rocky” Anderson \& Patrick A. Thronson, “Achieving Climate Protection: Fostering an Essential Focus on Human Rights and Human Impacts” (2013) 27 Notre Dame J.L. Ethics \& Pub. Pol’y 3, 17; see also Rahman (n9). 
as well as crops, which could create a food security problem for the nation..$^{9}$

Individuals living in poverty are particularly vulnerable to tropical cyclones, such as Jahanara Khatun. ${ }^{60}$ After tropical cyclone Aila hit Bangladesh in 2009, Khatun lost her husband and she was forced to sell her son and daughter into bonded servitude because of her impoverished situation. ${ }^{61}$ Her mud and bamboo hut was washed away by the cyclone in just a few minutes. ${ }^{62}$ Poor people are impacted the worst by climate change because of the poorly constructed housing that is prone to natural disasters. ${ }^{63}$ Upon the receipt of tropical cyclone warnings, some rural people choose not to evacuate, not because they do not want to leave, but because the shelters are too far away, overcrowded, or poorly maintained. ${ }^{64}$

\section{LEGAL FRAMEWORK AND POLICIES}

The Kyoto Protocol is an international agreement that addresses global climate change. ${ }^{65}$ Parties to the Protocol have a duty to reduce greenhouse gas emissions. ${ }^{66}$ The Protocol became effective in Bangladesh on 16 February 2005. ${ }^{67}$ Given that Bangladesh has done little to contribute to the climate change problem, ${ }^{68}$ the Kyoto Protocol is not an effective source

59 The Future We Want, “Bangladesh: Adapting to Coastal Climate Change” <http:/ /futurewewant.org/portfolio/bangladesh-adapting-to-coastal-climate-change/> accessed 30 July 2015.

60 Gardiner Harris, "Borrowed Time on Disappearing Land” (28 March 2014) $<$ www.nytimes.com/2014/03/29/world/asia/facing-rising-seas-bangladeshconfronts-the-consequences-of-climate-change.html?_r=1> accessed 30 July 2015.

61 ibid.

62 ibid.

63 Rural Poverty Portal (n38).

64 Amy Yee, "In Bangladesh, More Shelter From the Storms" (24 July 2013)<http:/ /opinionator.blogs.nytimes.com/2013/07/24/in-bangladesh-more-shelter-fromthe-storms/?_r=0> accessed 30 July 2015.

65 Kyoto Protocol to the United Nations Framework Convention on Climate Change (entered into force 10 Decmber 1997) 37 I.L.M. $22<$ http://unfccc.int/ resource/docs/convkp/kpeng.pdf>.

66 ibid.

67 United Nations Framework on Climate Change, "Status of Ratification of the Kyoto Protocol” <http://unfccc.int/kyoto_protocol/status_of_ratification/items/ 2613.php> accessed 30 July 2015 (Currently, there are 192 parties to the Kyoto Protocol).

68 United Nations (n2). 
of relief for Bangladeshi victims of climate change. In recent years, however, the UNFCCC developed new climate change adaptation plans, such as the Green Climate Fund of 2010 and the Warsaw International Mechanism on Loss and Damage of 2013, which are aimed at providing assistance to developing countries. ${ }^{69}$

The Green Climate Fund mandates that developed countries finance projects aimed to assist developing countries mitigate and adapt to the effects of climate change. ${ }^{70}$ The Warsaw International Mechanism on Loss and Damage requires countries to consider the potential loss and damage $\mathrm{p}^{71}$ that could occur "due to the adverse effects of climate change."72 Implementing the functions of the Loss and Damage Mechanism will require the Executive Committee to:

(1) Enhance the knowledge and understanding of comprehensive risk management approaches ...

(2) Strengthen dialogue, coordination, coherence, and synergies among relevant stakeholders ... and,

(3) Enhance action and support, including finance, technology and capacity-building, to address loss and damage associated with the adverse effects of climate change... ${ }^{73}$

Insurance and disaster management are mechanisms that can be used to deal with future loss and damage. ${ }^{74}$ Yet, these recent developments in international climate change adaptation could take years before yielding positive results. Thus, Bangladesh and the country's impoverished coastal communities must look toward other international laws, as well as domestic laws, in an effort to adapt to the global climate change problem.

69 See UN Convention (n 20) and accompanying text.

70 Laura Drummond, "UNFCCC Green Climate Fund Created" (2011) 11 Sustainable Dev. L. \& POL'y 69, 69.

71 "Loss and damage from climate change would refer to the complete and irrevocable loss of some things, [such as human life], and the repairable damage of other things, [such as roads or buildings], due to the impacts of human induced climate change." Saleemul Huq, "Loss and Damage: A Guide for the Confused" (20 October 2014) <www.rtcc.org/2014/10/20/loss-and-damage-a-guide-for-theconfused/> accessed 30 July 2015.

72 See Warsaw Mechanism for Loss and Damage (n19) and accompanying text.

73 ibid.

74 Huq (n71). 


\subsection{Domestic Measures}

The Bangladeshi government has enacted an extensive number of laws and policies with regard to climate change, disaster management, and basic human rights. ${ }^{75}$ These laws grant certain protections to victims of climate change and cyclones. ${ }^{76}$ More specifically, victims are entitled to the basic necessities of life $\mathrm{e}^{77}$ and proper infrastructure during times of disaster. ${ }^{78}$

\subsubsection{The Constitution of the People's Republic of Bangladesh}

In seeking redress from the harms caused by climate change, coastal communities of Bangladesh can turn to the supreme law of the land-the Constitution of Bangladesh. ${ }^{79}$ Article 15 of the Constitution of Bangladesh discusses the State's responsibility to furnish citizens with basic necessities. ${ }^{80}$ It states:

It shall be a fundamental responsibility of the State to attain, through planned economic growth, a constant increase of productive forces and a steady improvement in the material and cultural standard of living of the people, with a view to securing to its citizens (a) the provision of the basic necessities of life, including food, clothing, shelter, education and medical care ... ${ }^{81}$

In other words, the State is obligated to provide to its citizens, inter alia, the basic necessities of life such as shelter. ${ }^{82}$ This provision in the Constitution is a human rights guarantee; however, courts in Bangladesh have yet to address this issue. Therefore, examining case precedent in

75 See generally Displacement Solutions \& Young Power in Social Action, "Bangladesh Housing Land and Property (HLP) Rights Initiative: Climate Displacement in Bangladesh: Stakeholders, Laws and Policies - Mapping the Existing Institutional Framework" < http://displacementsolutions.org/wpcontent/uploads/Mapping-Study-Climate-Displacement-Bangladesh.pdf $>$ accessed 30 July 2015.

76 See generally Bangla. Const., art. 15; see ibid.; Coastal Zone Policy, 2005 (Bangladesh).

77 Bangla. Const., art. 15.

78 See Displacement Solutions (n75).

79 See generally Bangla. Const.

80 Bangla. Const., art. 15.

81 ibid art. 15(a).

82 Jona Razzaque, Public Interest Environmental Litigation in India, Pakistan, and Bangladesh (Kluwer Law International, 2004) 77. 
other countries with a similar human rights guarantee, such as India and South Africa, will be helpful in demonstrating the application of the fundamental right to shelter.

Part III of the Constitution of India identifies protected fundamental rights, and specifically, Article 21 describes a right to protection of life and personal liberty. ${ }^{83}$ In Francis Coralie Mullin $v$ The Administrator, Union Territory of Delhi $\mathcal{E}$ Ors., the Supreme Court of India expanded the scope of Article 21 and held that, "[T]he right to life includes the right to live with human dignity and all that goes along with it, namely, the bare necessaries of life such as adequate nutrition, clothing and shelter and facilities for reading, writing and expressing oneself in diverse forms ...." ${ }^{84} \mathrm{~A}$ few years later, the Court made a connection between the right to life and the right to adequate shelter in K. Chandru $v$ State of Tamil Nadu. ${ }^{85}$

In an effort to eradicate slums that were likely to become a source of danger to public health and sanitation, the State of Tamil Nadu enacted the Tamil Nadu Slum Areas (Improvement and Clearance) Act. ${ }^{86}$ Per the Act, about 450 roadside huts were to be demolished. ${ }^{87}$ The slum dwellers commenced an action against the State of Tamil Nadu seeking to receive alternative housing accommodations in the event of an eviction and basic amenities such as water, drainage and electricity. ${ }^{88}$ The government assured the slum dwellers that alternative accommodations would be made available. ${ }^{89}$ The Court stated that the right to life includes the right to livelihood and by evicting a person from their slum, which in this case is equivalent to a home, the State of Tamil Nadu is putting that individual's right to life in jeopardy. ${ }^{90}$ Therefore, the Court intimated that the right to life and the right to shelter are interconnected. ${ }^{91}$

In South Africa, section 26 of the Constitution of South Africa states that, "[e]veryone has the right to have access to adequate housing," and

83 India Const. art. 21.

84 Francis Coralie Mullin v. The Administrator, Union Territory of Debli E Ors., (1981) 1 S.C.R. (2) 516, 518 (India).

85 K. Chandru v. State of Tamil Nadu (1985) S.C.R. Supl. (2) 100, 101 (India).

86 ibid 100.

87 ibid.

88 ibid.

89 ibid.

90 ibid 102.

91 See generally K. Chandru v. State of Tamil Nadu (1985) S.C.R. Supl. (2) 100, 101 (India). 
it imposes a duty upon the state to take reasonable measures "[w]ithin its available resources, to achieve the progressive realization of this right." 92 This constitutional provision was addressed in Government of the Republic of South Africa $v$ Grootboom..$^{93}$ Similar to the situation in K. Chandru $v$ State of Tamil Nadu, Ms. Grootboom and others lived in an informal squatter settlement with no water, sewage, or adequate electricity. ${ }^{94}$ The majority of the settlement was composed of children, and those who lived there had very little money. ${ }^{95}$ As conditions worsened, Ms. Grootboom and other squatters applied for help from the local government, but never received a response. ${ }^{96}$ Thus, residents of the settlement moved their shacks to privately owned vacant land that was designated for low-income housing. ${ }^{97}$ The city evicted the petitioners by bulldozing and burning down their shacks, and left the families with nowhere to go. ${ }^{98}$

Ms. Grootboom and others sued the city, seeking temporary shelter that was adequate, or at least, receiving proper nutrition, healthcare, adequate shelter, and social services for the children..$^{99}$ The Constitutional Court of South Africa found that the state failed to oblige by section 26 of the Constitution ${ }^{100}$ and stated that

[T] he right of access to adequate housing ... entails more than bricks and mortar. It requires available land, appropriate services such as the provision of water and the removal of sewage and the financing of all of these, including the building of the house itself. For a person to have access to adequate housing, all of these conditions need to be met: there must be land, there must be services, [and] there must be a dwelling. ${ }^{101}$

92 S. Afr. Const., sec. 26(1)-(2), 1996.

93 Government of the Republic of South Africa v. Grootboom 2000 (11) SA 1 (CC) at 10-11,13 (S. Afr.).

94 ibid para 7.

95 ibid.

96 ibid para 8.

97 ibid.

98 ibid 8-9.

99 Government of the Republic of South Africa v. Grootboom 2000 (11) SA 1 (CC) 10, 13 (S. Afr.).

100 ibid 54, para 69.

101 ibid 29, para 35. 
Thus, the Court expanded the constitutional right of access to adequate housing to include all of these necessities and concluded that housing should be made available for all people, no matter what economic level of society they are in. ${ }^{102}$

The aforementioned cases, though not decided by the courts in Bangladesh, illustrate how the fundamental right to shelter has been applied in other countries. Some of the situations that were described in these cases are similar to the situations that many coastal families in Bangladesh face. Thus, these cases serve as persuasive authority in deciding similar issues in Bangladesh. Though they are not binding on the Bangladeshi judiciary, these cases may provide valuable guidance to Bangladeshi judges in making decisions with regards to housing and the right to shelter.

\subsubsection{Bangladesh's Climate Change Strategy and Action Plan}

The Bangladesh Climate Change Strategy and Action Plan (BCCSAP) was published in 2008 to address the negative impacts of climate change on the country, and to continue to implement the country's climate change adaptation and mitigation measures. ${ }^{103}$ Unlike the Kyoto Protocol, which sought to reduce the impacts of climate change through the regulation of greenhouse gas emissions, ${ }^{104}$ the BCCSAP serves as a guideline to tackle the negative impacts of climate change. ${ }^{105}$ Instead of trying to mitigate climate change, Bangladesh has chosen to adapt to the effects of climate change. ${ }^{106}$ This ten-year programme is designed to build the resilience of the vulnerable country, and it is built on six pillars: (1) food security, social protection, and health; (2) comprehensive disaster management; (3) infrastructure; (4) research and knowledge management; (5) mitigation

102 ibid.

103 Displacement Solutions (n75).

104 Kyoto Protocol (n65).

105 Abu Bakar Siddique, "Call for properly addressing global warming victims' rehabilitation" (29 January 2015) <www.dhakatribune.com/bangladesh/2015/ jan/29/call-properly-addressing-global-warming-victims \% E2\% 80\% 99rehabilitation> accessed 30 July 2015.

106 Natasha Gilbert, "Bangladesh launches climate change action plan” (11 September 2008) <www.nature.com/news/2008/080911/full/news.2008.1103.html> accessed 30 July 2015. 
and low carbon development; and, (6) capacity building and institutional strengthening. ${ }^{107}$

Pillars one through three are the most relevant to the devastating tropical cyclone problem in Bangladesh. The first pillar, addressing food security, social protection and health, focuses on providing basic necessities, such as food, housing, employment, and medical treatment for individuals impacted by climate change. ${ }^{108}$ The second pillar focuses on strengthening the disaster management procedures and systems, and the third pillar focuses on improving the existing infrastructure and building new infrastructure to respond to the impacts of climate change. ${ }^{109}$

Funding for the project comes from two sources - national funds and donations from the international community. ${ }^{110}$ In their annual budget, Bangladeshi officials allocated approximately $\$ 100$ million annually in the form of an endowment for the first three years of the project, which lasted from 2009 to $2012 .{ }^{111}$ This funding endeavour was known as the Bangladesh Climate Change Trust Fund (BCCTF). ${ }^{112}$ Sixtysix per cent of the amount in the trust fund was used to complete priority projects listed in the BCCSAP; and the remaining 34 per cent of the funds was saved for emergency situations. ${ }^{113}$ One of the projects funded by the BCCTF was a grant to construct cyclone-proof housing for those communities affected by Cyclone Aila in 2009. ${ }^{114}$

Notwithstanding this fund's laudable goals, the government decided to slash its budget for climate change funds. ${ }^{115}$ This decision came after a

107 Ministry of Environment and Forests, "Bangladesh Climate Change Strategy and Action Plan" <http://cmsdata.iucn.org/downloads/bangladesh_climate_ change_strategy_and_action_plan_2009.pdf > accessed 30 July 2015; see also Displacement Solutions (n75).

108 Displacement Solutions (n75).

109 ibid.

110 S.M. Munjural Hannan Khan et al, "The Bangladesh National Climate Funds" <https://ldcclimate.files.wordpress.com/2012/05/bangladeshnationalfund.pdf> accessed 30 July 2015.

111 ibid 4-5.

112 ibid 4.

113 ibid 5.

114 M. Zakir Hossain Khan, "Bangladesh: Cutting Off Our Heads to Cure a Headache” (3 July 2014) <https://blog.transparency.org/2014/07/03/ bangladesh-cutting-off-our-heads-to-cure-a-headache/> accessed 30 July 2015.

115 ibid., see also Syful Islam, "Bangladesh to slash its own climate adaptation fund" (18 June 2014) <www.trust.org/item/20140618092711-072sy/> accessed 30 July 2015. 
discovery of misuse of funds, and that political influence and corruption played a role in determining how funds should be allocated. ${ }^{116}$ Nongovernmental organizations that were responsible for managing climate adaptation projects had to bribe government officials with as much as 20 per cent of their own project money to have climate change funds released. ${ }^{117}$ Because of the corruption, the finance minister of Bangladesh "proposed no new funding for the BCCTF," thus forcing the country to rely on funds from donors. ${ }^{118}$

The Bangladesh Climate Change Resilience Fund (BCCRF) is a multidonor trust fund that receives contributions from four main donors - the United Kingdom, Denmark, Switzerland, and the European Union. ${ }^{119}$ The World Bank has also contributed over $\$ 300$ million to the BCCRF, which has gone towards rebuilding cyclone shelters and constructing new shelters. ${ }^{120}$ By relying solely on donor-funded climate adaptation projects, donors may provide their expertise and modern technology on adaptation, which is something that Bangladesh lacks; ${ }^{121}$ but, by cutting the BCCTF, donors may get the impression that the Bangladeshi government is not willing to pay its portion of the climate adaptation projects. ${ }^{122}$ Thus, donors may be discouraged from making future contributions to the national climate change trust fund, ${ }^{123}$ which makes the future of the climate change adaptation fund bleak.

\subsubsection{Coastal Zone Policy and Coastal Development Strategy}

In an effort to provide better management and development of the coasts, the Bangladeshi government enacted the Coastal Zone Policy in 2005. ${ }^{124}$

116 Islam (n115).

117 The Daily Star, "NGOs had to spend 20pc of climate funds on bribe: TIB" (4 October 2013) <http://archive.thedailystar.net/beta2/news/ngos-had-tospend-20pc-of-climate-funds-on-bribery-tib/> accessed 30 July 2015.

118 Islam (n115).

119 S.M. Munjural Hannan Khan et al. (n110).

120 Ruma Paul, "World Bank expands support to Bangladesh cyclone victims" (11 March 2014) <http://in.reuters.com/article/2014/03/11/bangladesh-cyclonesworldbank-idINDEEA2A06J20140311> accessed 30 July 2015.

121 Islam (n115).

122 ibid.

123 ibid.

124 Enamul Mazid Khan Siddique \& Ahana Adrika, "Sustainable Coastal Zone Management of Bangladesh" (Report in Mangroves for the Future) (January 2011) <www.mangrovesforthefuture.org/assets/Repository/Documents/ Sustainable-Coastal-Zone-Management-of-BangladeshMFF.pdf $>$ accessed 30 July 2015. 
The policy aims "to create conditions, in which the reduction of poverty, development of sustainable livelihoods and the integration of the coastal zone into national processes can take place." ${ }^{125}$ Because one-third of the country is located in the coastal territory, and about 48 upazilas ${ }^{126}$ are exposed to natural disasters, the government must take special measures during the period of a disaster and khas land ${ }^{127}$ shall be distributed among the landless people. ${ }^{128}$

The Act also imposes a duty on the government to reduce vulnerabilities to natural disasters by enhancing safety measures, such as shelters, infrastructure, embankments, and disaster warning systems. ${ }^{129}$ Notably, due to the unequal distribution of resources, the poor, neglected, and disadvantaged groups do not have access to economic and social opportunities. Consequently, the Act calls for equitable distribution of resources and economic benefits to uphold the rights of disadvantaged groups and reach the poorest and cyclone-prone regions of the country. ${ }^{130}$

Shortly after the Coastal Zone Policy was enacted, government officials enacted the Coastal Development Strategy (CDS), which was designed to implement the Coastal Zone Policy. ${ }^{131}$ The CDS focuses on nine projects in the coastal zone. ${ }^{132}$ Two of those priorities involve ensuring the safety of coastal people from man-made and natural hazards, and improving the livelihood conditions of people, especially women. ${ }^{133}$ In addressing safety from man-made and natural disasters, the CDS states

125 Rafiqul Islam, "Pre-and Post-Tsunami Coastal Planning and Land-Use Policies and Issues in Bangladesh" <www.fao.org/forestry/13138-098e3e2e57aa60088543 a509788445c8d.pdf $>$ accessed 30 July 2015; Kazi Shakila Islam et al., "Successful Integrated Coastal Zone Management (ICZM) Program Model of a Developing Country (Xiamen, China) - Implementation in Bangladesh Perspective" (2009) 2 Journal of Wetlands Ecology 35, $37<$ www.loiczsouthasia.org/ pdfdocuments/Bangladesh_ICZM_Plan.pdf> accessed 30 July 2015.

126 An upazila is a political subdivision in Bangladesh, similar to a county. The Free Dictionary, "Upazila” <http://financial-dictionary.thefreedictionary.com/ Upazilas+of+Bangladesh> accessed 30 July 2015.

127 Khas land is state land; however, state land is scarce. Through the process of accretion, state land is gained. Rafiqul Islam (n125).

128 Coastal Zone Policy, 2005 (Bangladesh).

129 ibid art. 4.3(e).

130 ibid art. 4.5 .

131 ibid art. 5.3; Displacement Solutions (n75).

132 Coastal Development Strategy, 2006 (Bangladesh) <http://www.warpo.gov.bd/ pdf/coastalDevPolicy.pdf> accessed 30 July 2015.

133 ibid. 
that better preparedness for disasters will aid in reducing death tolls and that by creating a "long-term comprehensive disaster management programme," coastal communities will be able to handle disasters much better. ${ }^{134}$ To improve the livelihood conditions of people, the CDS aims to reduce poverty by generating employment opportunities for the poor and disadvantaged..$^{135}$

\subsection{International Protections}

Under international law, the coastal communities of Bangladesh can remedy their situation through human rights treaties. The protections guaranteed by international human rights laws are used as another avenue for individuals seeking redress for harms caused by global climate change because rights to life, health, shelter, food, and water are all affected by the impacts of climate change. ${ }^{136}$ Over the last few years, experts working under the UN Framework Convention on Climate Change (UNFCCC) have discovered a link between international climate change and human rights. ${ }^{137}$ This led the Human Rights Council to adopt Resolution 7/23, which states that climate change is entangled with and has some sort of impact on the full enjoyment of human rights. ${ }^{138}$

The Universal Declaration of Human Rights (UDHR), adopted by the United Nations (UN) General Assembly in 1948, was one of the first international legal instruments that called for basic civil, political, economic, social, and cultural rights. ${ }^{139}$ Article 25, Section 1 of the UDHR specifically addresses the standard of living and states, "Everyone has the right to a standard of living adequate for the health and well-being of himself and of his family, including food, clothing, housing and medical care and necessary social services ...”. ${ }^{140}$

134 ibid art. 1.5.

135 ibid.

136 Int'l Bar Ass'n (n16).

137 Megan M. Herzog, "Coastal Climate Change Adaptation and International Human Rights" in Randall S. Abate (ed), Climate Change Impacts on Ocean and Coastal Law: U.S. and International Perspectives 606 (Oxford University Press, 2015) 606; see also Int'l Bar Ass'n (n16).

138 Human Rights Council Res. 7/23, Rep. of the Human Rights Council, 7th Sess., March 3-28, 2008, A/HRC/7/78 (Mar. 28, 2008); see ibid.

139 ibid 601.

140 Universal Declaration of Human Rights (adopted 10 December 1948) UNGA Res 217 (III) A (UDHR) art 25(1). 
Observably, establishing a human rights violation requires a binding source of public international law that identifies someone with a duty, as well as someone holding a right, and causation - "evidentiary proof that the duty-bearer's failure to fulfil its legal responsibility threatened or impeded the right-holder's enjoyment of [his or] her legally protected right or entitlement." ${ }^{141}$ The UDHR is not binding on nation-states, but legal experts argue that some of the rights expressed in the declaration have "risen to the level of customary international law," which can be binding on nation-states. ${ }^{142}$ Nevertheless, the UDHR is simply "a powerful and authoritative statement of the customary international law of human rights" 143 and does not meet the requirements of a binding international agreement.

In response to this notion, the UN General Assembly created a binding human rights treaty known as the International Covenant on Economic, Social and Cultural Rights (ICESCR). ${ }^{144}$ Article 11 of the Covenant addresses the adequate standard of living, similar to that found in the UDHR. ${ }^{145}$ Article 11 recognizes "the right of everyone to an adequate standard of living for himself and his family, including adequate food, clothing and housing, and to the continuous improvement of living conditions, and the fundamental right of freedom from hunger." 146 The treaty imposes a duty on states to take the necessary steps to "ensure the realization of this right." ${ }^{147}$ General Comment No. 4 to Article 11 discusses in detail the right to adequate housing, and states that the housing should be habitable and accessible, especially to those victims of natural disasters. ${ }^{148}$ When determining what social groups are entitled to adequate housing, state parties must prioritize those communities living in unfavourable conditions. ${ }^{149}$ Bangladesh ratified this treaty in $1998 .{ }^{150}$

141 Herzog (n137).

142 ibid.

143 Siderman de Blake v. Republic of Argentina, 965 F.2d 699, 719 (9th Cir. 1992); Hawkins v. Comparet-Cassani, 33 F. Supp. 1244, 1257 (C.D. Cal. 1999).

144 Herzog (n137).

145 International Covenant on Economic, Social and Cultural Rights (adopted 16 December 1966) 6 ILM 360 (ICESCR) art 11.

146 Anderson \& Thronson (n58).

147 ICESCR (n145).

148 UN Committee on Economic, Social and Cultural Rights (CESCR), General Comment No. 4: The Right to Adequate Housing (Art. 11(1) of the Covenant) (13 Dec. 1991), E/1992/23.

149 ibid.

150 Status of Ratification Interactive Dashboard, United Nations Human Rights, http://indicators.ohchr.org/ (in list of countries to left, click "Bangladesh"). 


\subsection{Existing Flood Insurance Programme}

In August of 2013, Oxfam Bangladesh developed a flood insurance plan for the poor and vulnerable people living in Bangladesh. ${ }^{151}$ "The MesoLeve ${ }^{152}$ Based Flood Insurance Project is a unique attempt to protect the low-income, vulnerable river basin communities by improving their ability to cope with flood risks." 153 The targeted areas for the new product are the river basin areas of the Sirajganj district in Bangladesh. ${ }^{154}$ The Sirajganj district is located along the Jamuna River in Northern Bangladesh, far away from the coast. ${ }^{155}$ While the programme was initiated by Oxfam, the India Based Centre for Insurance and Risk Management (CIRM), the Institute of Water Modelling of Bangladesh (IWM), Swiss Development Corporation, Swiss Re, Pragati Insurance Ltd, Manab Mukthi Sangstha (MMS), ${ }^{156}$ and Palli Karma Sahayek Foundation have joined with Oxfam to implement the flood insurance plan. ${ }^{157}$ Each corporation has contributed to the project as follows: Oxfam has taken on the role of the project lead; Swiss Development Corporation finances the entire project; CIRM has designed the plan; IWM provides the flood

151 Dhaka Tribune, “First ever flood insurance scheme launched” (21 August 2013) $<$ www.dhakatribune.com/safety/2013/aug/21/first-ever-flood-insurancescheme-launched> accessed 30 July 2015.

152 The meso-level of review falls between the micro and macro levels of review. Those who use a meso-level of review typically study mid-scale societies, such as communities, villages, or neighborhoods, as opposed to macro-level reviewers who study nations or states as a whole. AppliedSoc, 'Applying Sociology Within Various Society Levels'<www.appliedsoc.org/society/> accessed 30 July 2015.

153 Oxfam in Bangladesh (n37).

154 Canadian Underwriter, “Oxfam, Swiss Re project brings flood insurance to Bangladeshi villages” (20 August 2013) <www.canadianunderwriter.ca/news/ oxfam-swiss-re-project-brings-flood-insurance-to-bangladeshi-villages/ 1002542575/?\&er=NA > accessed 30 July 2015.

155 Sirajganj, Bangladesh, Google Maps, <www.google.com/maps/place/ Sirajganj,+Bangladesh/@24.0698844,90.3219508,8z/data $=! 4 \mathrm{~m} 2 ! 3 \mathrm{~m} 1$ ! $1 \mathrm{~s} 0 \mathrm{x} 39$ fdc1df830dba1b:0x58f0cbb092e78b62> (zoom out for a full view of the country).

156 Manab Mukthi Sangstha is a local non-governmental organization located in the Sirajganj district of Bangladesh with a vision to create a "poverty and discrimination free society where people will have adequate capacity to protect themselves from vulnerability of natural disasters." The organization works mainly in disaster prone and poverty stricken areas and provides aid to victims of riverbank erosions and flooding. Manab Mukthi Sangsta, "Background of the Organization" < www.mmsbangladesh.org/about-mms/> accessed 30 July 2015.

157 ibid. 
data; Pragati Insurance Ltd is the primary insurer; Swiss Re is the reinsurer; and MMS is the policy holder. ${ }^{158}$

The programme is index-based, ${ }^{159}$ meaning that the pay-out is triggered on the basis of a certain threshold being reached, as opposed to assessing losses on a case-by-case basis. ${ }^{160}$ In this case, the threshold is the water depth and the duration of the flooding. ${ }^{161}$ Through the use of gauges, IWM calculates the flood water levels throughout the region ${ }^{162}$ and, at the end of the monsoon season, the policyholder receives the flood insurance compensation. ${ }^{163}$ That money is then distributed to the households that meet the compensation criteria. ${ }^{164}$ The plan covers fourteen villages in the Sirajganj district, which amounts to 1,661 families. ${ }^{165}$

In the event of a catastrophic flood, affected households are eligible to receive up to 8,000 Bangladeshi taka, or US $\$ 100,{ }^{166}$ without ever having to pay a single penny in insurance premium. ${ }^{167}$ The plan has been broken down into a multi-tiered compensation payment schedule that determines how much money a household is entitled to, based on the duration of the flood. ${ }^{168}$ "If water levels cross a certain locally-determined threshold and

158 Oxfam in Bangladesh (n 37).

159 The benefit of having an index-based program, as opposed to a traditional insurance plan, is that beneficiaries are paid out faster and the money is more useful, versus having to wait until the tragic event occurs and then receiving insurance compensation. Irin, "New-concept flood insurance could help Bangladesh's poor” (11 April 2014) <www.irinnews.org/report/99928/newconcept-flood-insurance-could-help-bangladesh-s-poor> accessed 30 July 2015.

160 ibid.; see also Index Based Livestock Insurance, "FAQs" <https:// livestockinsurance.wordpress.com/faqs/> accessed 30 July 2015 (explaining what index-based flood insurance is).

161 Swiss Re, "Bangladesh flood victims benefit from first index insurance payout" (31 October 2014) <www.swissre.com/global_partnerships/Bangladesh_flood_ victims_benefit_from_first_index_insurance_payout.html> accessed 30 July 2015.

162 Oxfam, "Developing Alternative Risk Transfer Mechanism of Disaster \& Climate Vulnerable Communities" <http://oxfamblogs.org/bangladesh/wpcontent/uploads/2013/08/Project-Brochure.pdf $>$ accessed 30 July 2015; OxfaminBangladesh (n 37); see also Dhaka Tribune (n 151).

163 Swiss Re (n 161).

164 ibid.

165 Dhaka Tribune (n 151); see also Oxfam (n 162).

166 Canadian Underwriter (n 154); see also Dhaka Tribune (n 151).

167 OxfaminBangladesh (n 37).

168 ibid., see also Irin (n 159). 
stay[s] for 11 days, a household will get 2,800 taka," which is equal to US $\$ 36 .{ }^{169}$ After 21 days of flooding, the household is compensated with 4,400 taka or US\$56; and, once there has been 26 days of flooding, the household receives 8,000 taka. ${ }^{170}$ This programme has instilled a sense of security in people who are regular victims of flooding. ${ }^{171}$

In October 2014, the victims of the August and September 2014 floods received the first flood insurance pay-out since the programme became effective in 2013. ${ }^{172}$ More than 700 families received the Bangladeshi equivalent of US $\$ 25,000$ to rebuild their lives. ${ }^{173}$ The pay-out has helped a large number of victims get back on their feet without having to worry about selling off their life-essential assets or borrowing money on highinterest short-term loans. ${ }^{174}$ Oxfam's Country Director in Bangladesh has expressed hopes that the flood insurance concept will be "scaled up" and extended to the rest of the country. ${ }^{175}$ However, the plan is yet to be implemented along the coasts, which are at high risk for tropical cyclones and floods caused by storm surges. ${ }^{176}$

\section{PROPOSAL TO INSURE AND SHELTER COASTAL COMMUNITIES}

Enforcement of the constitutional right to shelter would require the government and other organizations to provide assistance to those people living along the coasts of Bangladesh. This assistance can come in the form of flood insurance, which would indicate that there is a constitutional right to flood insurance; or it can come directly from the government in the form of a cash pay-out to affected households. However, in order to ensure that these funds are being made available to vulnerable coastal families, enforcement of international socio-economic human rights protections need to be improved.

169 Irin (n 159).

170 ibid.

171 Canadian Underwriter (n 154).

172 Swiss Re (n161).

173 ibid.

174 ibid.

175 ibid.; see also Dhaka Tribune (n151); see also Canadian Underwriter (n 154).

176 See generally Natural Disasters (n 50). 


\subsection{Mitigating Property Losses by Establishing a Constitutional \\ Right to Flood Insurance and Extending Flood Insurance Coverage to Impoverished Coastal Communities}

As coastal houses and communities are being washed away by tropical storm surges, so are the rights of the individuals living along the coasts. Without any help from the government, these people have no place to go. Thus, the constitutional right to food, clothing, and shelter, as outlined in Article 15 of the Constitution of Bangladesh, ${ }^{177}$ encompasses an obligation for the State to provide flood insurance to the impoverished coastal communities of Bangladesh. Flood insurance provides individuals and families with a sum of money that can assist them in the rebuilding process after a flood has occurred. ${ }^{178}$ Thus, offering flood insurance is a method by which the government can fulfil its duties under Article 15 of the Constitution and provide families with the basic necessities they need.

The index-based flood insurance that is currently being offered along the northern river plains of Bangladesh can be viewed as an effective programme for a developing country; however, the flood insurance should be extended to households all over the country, especially those living along the coasts. Because coastal communities face a constant threat of tropical cyclones and sea-level rise, ${ }^{179}$ it makes sense to offer flood insurance for residents along the coasts in an effort to comply with Article 15 of the Bangladeshi Constitution as well as global human rights laws.

The National Flood Insurance Program (NFIP) in the United States offers a number of benefits that may be useful to coastal Bangladeshis. ${ }^{180}$ Flood insurance compensates policy holders for all covered losses and policy holders have more control over the situation because, even if the president does not declare a state of emergency, policy holders would still be reimbursed for flood damages. ${ }^{181}$ The NFIP may have its flaws, but the amount of control that policy holders have over emergency situations is something that could benefit Bangladeshi nationals.

177 Bangla. Const., art. 15.

178 See generally Canadian Underwriter (n 154).

179 See generally Natural Disasters (n 50).

180 MetLife, "Learn the Basics - Benefits of Flood Insurance" <www.metlifega.com/ Products/Flood/LearntheBasics/BenefitsofFloodInsurance/tabid/252/ Default.aspx $>$ accessed 30 July 2015.

181 ibid. 
Currently, flood-insured citizens of Bangladesh have to rely on a number of people to evaluate the situation before they are compensated. ${ }^{182} \mathrm{By}$ implementing a system similar to the NFIP, Bangladeshi citizens would have more control over the receipt of flood insurance compensation during emergency situations. They would not have to wait for every party involved in the flood insurance programme to evaluate the situation and determine pay-outs.

Apart from the strong level of control that policy holders have with the NFIP, the flood insurance programme that is currently offered in Bangladesh includes similar benefits, but it is not being offered nationwide. ${ }^{183}$ Studies have shown that after a disaster strikes, those floodprone rural communities, such as coastal communities in Bangladesh, often engage in "extreme coping mechanisms, including [obtaining] highinterest short terms loans and selling [off] life-essential assets such as cows and goats" in an effort to lessen the burden that is felt after a flood. ${ }^{184} \mathrm{But}$ with flood insurance, these victims do not have to engage in such coping mechanisms because flood insurance money enables victims to rebuild their lives and livelihoods. ${ }^{185}$ Therefore, flood insurance needs to be offered nationwide, so that the vulnerable coastal families can enjoy such benefits.

In the United States, some of the most affluent individuals and families live in large coastal metropolises near the water. ${ }^{186}$ These individuals benefit the most from flood insurance, but at the expense of low-income

182 Oxfam in Bangladesh (n 37).

183 Swiss Re (n 161).

184 UNB, "Flood victims get insurance benefit for first time" (1 November 2014) $<w w w . t h e i n d e p e n d e n t b d . c o m / i n d e x \cdot p h p$ ?option $=$ com_content\&view $=$ article\&id=235534:flood-victims-get-insurance-benefit-for-firsttime\&catid=95:national\&Itemid=141> accessed 30 July 2015.

185 ibid.

186 Danielle Kurtzleben, "Where the Richest Americans Live” (12 February 2013) $<$ www.usnews.com/news/articles/2013/02/12/where-the-richest-americanslive $>$ accessed 30 July 2015.

187 Laura Bassett, "FEMA Flood Insurance Program Primarily Benefits The Wealthy: Study" (21 June 2010) <www.huffingtonpost.com/2010/04/21/femaflood-insurance-prog_n_546135.html> accessed 30 July 2015 (The way the FEMA flood insurance program works is that FEMA offers discounted flood rates to people who build houses in high-risk areas, such as coastal areas, and then, when disaster strikes, taxpayers ultimately pay the bill); see also Christopher Matthews, "Should the Federal Government Be Subsidizing Flood Insurance?” (30 October 2012) <http://business.time.com/2012/10/30/shouldthe-federal-government-be-subsidizing-flood-insurance/> accessed $30 \mathrm{July}$ 2015. 
individuals. ${ }^{187}$ But, in Bangladesh, a large number of impoverished families live along the coasts, ${ }^{188}$ while wealthy Bangladeshi families live in major urban cities, such as Dhaka and Khulna which are both away from the water. ${ }^{189}$ These inland cities have the privilege of being protected by flood insurance. ${ }^{190}$ The failure to offer flood insurance for impoverished coastal families, and instead, offering such coverage to families located inland, raises the issue of discrimination. Such discrimination can be a hurdle in the fight against poverty and can further the impacts of poverty. ${ }^{191} \mathrm{By}$ offering nationwide flood insurance, Bangladeshi officials can alleviate the impacts of poverty in compliance with the Coastal Zone Policy ${ }^{192}$ and reduce the possibility of socio-economic discrimination.

\subsection{Restoring the Climate Change Trust Fund Act (National Climate Change Funding System) to Provide Housing and Better Infrastructure}

Under the current flood insurance programme in place along the riverbeds in the northern region of the country, the funding for flood insurance is coming from a private company in another country and the funds are being distributed to a non-governmental organization in Bangladesh. ${ }^{193}$ Therefore, the Bangladeshi government is not contributing to the fund and the money passes through a third-party before reaching the affected households. ${ }^{194}$ By failing to contribute to the flood insurance programme, the state is doing nothing to secure housing for its poor and disadvantaged citizens along the coast, thus violating not only the Constitution, but also other legislative acts such as the Coastal Zone Policy. The state is also in direct violation of global human rights laws that establish a right

188 Rural Poverty Portal (n 38).

189 Encyclopedia of the Nations, "Bangladesh - Poverty and wealth" $<$ www.nationsencyclopedia.com/economies/Asia-and-the-Pacific/BangladeshPoverty-and-wealth.html> accessed 30 July 2015.

190 See generally Dhaka Tribune (n 151).

191 Human Rights Watch, "Discrimination, Inequality, and Poverty - A Human Rights Perspective” (12 January 2013) <www.hrw.org/news/2013/01/11/ discrimination-inequality-and-poverty-human-rights-perspective $>$ accessed 30 July 2015.

192 Coastal Zone Policy, 2005 (Bangladesh).

193 OxfaminBangladesh (n 37).

194 See generally Swiss Re (n 161).

195 Anderson \& Thronson (n 58). 
to shelter, ${ }^{195}$ because, under all of these laws and policies, the state has the duty to provide adequate housing for its citizens. ${ }^{196}$ And with the current flood insurance programme, the Bangladeshi government has shunned nearly all its responsibilities and let a foreign organization take the responsibility of providing for the Bangladeshi people. ${ }^{197}$

Despite the corruption and heavy political influence, the national climate change trust fund was a ray of hope for those communities affected by climate change and natural disasters. The Bangladeshi government is no stranger to political corruption. ${ }^{198}$ Improper building safety inspections and failure to maintain factories in accordance with building codes led to the collapse of a garment factory in Bangladesh, which resulted in more than 600 deaths. ${ }^{199}$ The government failed to heed warnings of the unsafe building conditions due to the corruption within the system. ${ }^{200}$ Such political corruption could also cost the lives of impoverished people living along the coasts of Bangladesh, who do not have proper infrastructure to evacuate during storms, and do not have adequate shelters and homes.

Relying solely on the BCCRF and the international community may not bring about the infrastructure improvements that are needed to alleviate the impacts of tropical cyclones on coastal communities because the BCCRF puts the future of funding for climate adaptation projects in the hands of countries and organizations that are not as vulnerable as

196 See Part II, Section B (discussing international human rights and the state's duties under those laws).

197 See generally Swiss Re (n 161).

198 See generally Transparency International, "In Bangladesh, Corruption Kills Hundreds” Transparency (26 April 2013) < www.transparency.org/news/ feature/in_bangladesh_corruption_kills_hundreds> accessed 30 July 2015.

199 ibid.

200 Muhammad Abdul Bari, "Bangladesh Factory Deaths: Deep-Rooted Corruption Behind a Human Tragedy” (30 April 2013) <www.huffingtonpost.co.uk/ muhammad-abdul-bari/bangladesh-factory-deaths_b_3178559.html?> accessed 30 July 2015.

201 S.M. Munjural Hannan Khan et al. (note 110) (donors to the fund include the United Kingdom, Denmark, and Switzerland). According to research conducted by the Notre Dame Global Adaptation Index (ND-GAIN), countries in Africa and South Asia are most vulnerable to climate change. The ND-GAIN research resulted in three color-coded maps that displayed a country's potential vulnerability to climate change. Europe, which is home to the United Kingdom, Denmark, and Switzerland, was coded in green, indicating that the continent is least vulnerable to climate change impacts. Ana Swanson, "The countries most vulnerable to climate change, in 3 maps" (3 February 2015) <www.washington post.com/news/energy-environment/wp/2015/02/03/the-countries-mostvulnerable-to-climate-change-in-3-maps/> accessed 30 July 2015. 
Bangladesh to climate change impacts. ${ }^{201}$ The national climate change trust fund could be a source of funds for a government-sponsored flood insurance programme, similar to the NFIP in the United States. ${ }^{202}$ And, due to the poor economic situations that the majority of these coastal families are in, some form of financial support from the government is needed to develop an insurance programme for flood damage. ${ }^{203}$ The national climate change trust fund was an avenue for government involvement in the rebuilding of communities adversely impacted by climate change.

National climate change adaptation funds could be used to rebuild roads and buildings that have been destroyed by tropical cyclones. Such use of the national funds would fall within the scope of the policy behind the Warsaw International Mechanism on Loss and Damage. Thus far, the Bangladeshi government has been able to address disasters to some degree, but its response to natural disasters is still slow. ${ }^{204}$ The national climate change adaptation fund will allow the government to focus on creating an effective disaster management programme and early warning system. The funds will help the government be better prepared for disasters and allow them to provide some protection for their citizens. As a result, death tolls will be reduced and the livelihoods of many coastal families will be more stable.

\subsection{Improving Enforcement of International Socio-Economic Human Rights Protections in Bangladesh through Increased Accessibility to Judicial Measures and Remedies}

There are a variety of methods used to enforce international human rights treaties and covenants, ${ }^{205}$ including international and regional commissions, tribunals, and the UN Human Rights Commission. ${ }^{206}$ The

202 Jennifer Wriggins, "Flood Money: The Challenge of U.S. Flood Insurance Reform in a Warming World" (2014) 119 Penn St. L. Rev. 361, 367.

203 W.J. Wouter Botzen, Managing Extreme Climate Change Risks Through Insurance (Cambridge University Press, 2013) 315.

204 Abu Bakar Siddique, "Bangladesh not ready for the big one" (27 April 2015) <www.dhakatribune.com/bangladesh/2015/apr/27/bangladesh-not-ready-bigone $>$ accessed 30 July 2015.

205 Legal Information Institute Cornell University Law School, "Human Rights" <www.law.cornell.edu/wex/human_rights> accessed 30 July 2015.

206 International Justice Resource Center, "Overview of the Human Rights Framework" <www.ijrcenter.org/ihr-reading-room/overview-of-the-humanrights-framework/> accessed 30 July 2015. 
problem with enforcement of the right to shelter lies with Bangladeshi officials and the state's judicial system, however. The country has undertaken ambitious measures to protect civil and political human rights, ${ }^{207}$ but has failed to address enforcement of socio-economic human rights, which include the right to shelter. ${ }^{208}$ The lack of case law addressing the right to shelter is indicative of this problem. However, many individuals argue that socio-economic human rights, as opposed to civil and political rights, are not "real" human rights. ${ }^{209}$ They also argue that socio-economic human rights are not immediately enforceable in a court of law, thus they are not afforded judicial protection. ${ }^{210}$ But, because Bangladesh became a party to the ICESCR in 1998, the state assumed various duties under the covenant, and "must take positive action to facilitate the enjoyment of basic human rights," 211 even the socio-economic human rights. Therefore, the Bangladeshi judiciary needs to step in.

In South Africa, some scholars have proposed the use of "structural interdicts" ${ }^{212}$ to improve enforcement of socio-economic human rights. ${ }^{213}$ These structural interdicts are designed to force any human rights violators to remedy the breach under court supervision. ${ }^{214}$ Thus, government officials are required to present their proposals for rectifying the breach to the court for court approval. ${ }^{215}$ This would improve government

207 Civil and political human rights include the prohibition of torture and slavery, right to a fair trial, right to privacy, right to nationality, right to own property, etc. Claiming Human Rights, "General Civil and Political Rights" $<$ www.claiminghumanrights.org/general_civil_political_rights.html > accessed 30 July 2015.

208 Human Rights Watch, "Human Rights in Bangladesh" <www.hrw.org/asia/ Bangladesh> accessed 30 July 2015.

209 Stanley Ibe, "Yes, Economic and Social Rights Really Are Human Rights" (8 August 2014) <www.opendemocracy.net/openglobalrights/stanley-ibe/yeseconomic-and-social-rights-really-are-human-rights $>$.

210 ibid.

211 United Nations Human Rights, “International Human Rights Law” $<$ www.ohchr.org/EN/ProfessionalInterest/Pages/InternationalLaw.aspx> accessed 30 July 2015.

212 An interdict is "any prohibitory act or decree of a court or an administrative officer.” Dictionary.com, “Interdict” < http://dictionary.reference.com/browse/ interdict> accessed 30 July 2015.

213 Mitra Ebadolahi, "Using Structural Interdicts and the South African Human Rights Commission to Achieve Judicial Enforcement of Economic and Social Rights in South Africa” (2008) 83 N.Y.U. L. Rev. 1565, 1591.

214 ibid.

215 ibid 1596.

216 ibid. 
accountability, and help authorities comply with the law. ${ }^{216}$ Structural interdicts would also preserve the court's role in interpreting laws and ensuring that government proposals are not discriminatory. ${ }^{217}$

Notably, another protection issue arises when trying to improve the enforcement of the right to shelter through accessibility to judicial remedies and measures. Looking at the spectrum of civil and political rights, cases addressing those rights are generally brought by the most affluent, articulate, and assertive individuals. ${ }^{218}$ Whereas, the most disadvantaged, impoverished, and vulnerable people are unable to voice their claims to the court, and the cases that are brought before the court are decided without taking into account the impacts on such people. ${ }^{219}$ This is where judicial activism and public interest litigation would play a role.

Judicial activism implies that courts are activists when they change the law, resolve disputes, and decide on policies. ${ }^{220}$ Under the Constitution of Bangladesh, high courts are given the power to make orders directing a person or people to refrain from engaging in a prohibited act. ${ }^{221}$ Public interest litigation has played a significant role in implementing this power of the courts. ${ }^{22}$ Public interest litigation "is defined as the use of litigation, or legal action, which seeks to advance the cause of minority or disadvantaged groups or individuals, or which raises issues of broad public concern." ${ }^{223}$ In these types of actions, the courts play a much bigger role. ${ }^{224}$ And, because they are so different from traditional actions, courts are

217 ibid.

218 Ellen Wiles, “Aspirational Principles or Enforceable Rights? The Future for Socio-Economic Rights in National Law” (2006) 22 Am. U. Int'l L. Rev. 35, 56.

219 ibid., see also Mohammad Sohidul Islam, “A Human Right to Water: Challenges and Opportunities for Ensuring this Right in Bangladesh" (2014) 15 Australian J. of Asian Law 1, $10<$ http://papers.ssrn.com/sol3/papers.cfm?abstract_id $=2587625>$.

220 Islam, Human Right to Water (n 219).

221 Bangla. Const., art. 102; see also ibid.

222 See generally Islam, Human Right to Water (n 219).

223 The PILS Project, “About Public Interest Litigation” < www.pilsni.org/aboutpublic-interest-litigation> accessed 30 July 2015.

224 See generally Basant Lal Wadehra, Public Interest Litigation: A Handbook, with Model PIL Formats (Universal Law Publishing Co Ltd, 2009) 59.

225 ibid. 
more assertive and creative when dealing with public trust actions. ${ }^{225}$

In recent years, throughout South Asia, public interest litigation has been linked with enforcing environmental laws. ${ }^{226}$ Yet, the concept was introduced through human rights violations. ${ }^{227}$ Restructuring the link between public interest litigation and enforcement of fundamental human rights will be key in providing protection to coastal families who have been deprived of shelter due to the effects of tropical cyclones and climate change.

The advantages of bringing public interest actions to advance Bangladesh's vulnerable coastal communities claims to a fundamental right to shelter are that such actions provide access to justice for disadvantaged groups, create an avenue for reformation of unfair laws, hold the government accountable for the actions, and raise awareness on certain issues. ${ }^{228}$ Public interest litigation has been received in a positive light in India, Bangladesh's neighbouring country.229 Public interest litigation in India has brought courts closer to disadvantaged groups, helped in expanding jurisprudence of fundamental human rights to include socioeconomic human rights, and fought corruption in administration. ${ }^{230}$ Through this form of litigation, the Indian society has gained more confidence and trust in their judiciary. ${ }^{231}$ Moreover, public interest litigation in India has been an example for other South Asian countries. ${ }^{232}$ One drawback of India's public interest litigation, however, is that is creates a larger influx of cases in the Indian courts, thus leading to a lack of judicial capacity to resolve these cases effectively. ${ }^{233}$

226 Pravez Hassan \& Azim Azfar, "Securing Environmental Rights Through Public Interest Litigation in South Asia” (2004) 22 Va. Envtl. L.J. 215, 223.

227 Jona Razzaque, "Linking Human Rights, Development, and Environment: Experiences from Litigation in South Asia” (2007) 18 Fordham Envtl. L. Rev. 587, 588.

228 The PILS Project (n 223).

229 Surya Deva, "Public Interest Litigation in India: A Critical Review" (2009) 28 Civil Justice Quarterly 19, 31 <http://unpan1.un.org/intradoc/groups/public/ documents/apcity/unpan047384.pdf> accessed 30 July 2015.

230 ibid.

231 ibid 32.

232 ibid.

233 ibid 33. 


\section{CONCLUSION}

Climate change impacts, such as sea level rise and devastating tropical cyclone activity, pose multidimensional threats to daily life and survival in Bangladesh's coastal communities. ${ }^{234}$ Without adequate legal and policy responses, the coasts of Bangladesh would be under the threat of submersion like the Maldives - a tiny island nation in the Indian Ocean. ${ }^{235}$

Flood insurance is a relatively inexpensive solution to the climate change impacts occurring along the coasts of Bangladesh as opposed to projects such as coastal restoration or beach re-nourishment. By extending flood insurance to the coasts to help victims that are most impacted by climate change, Bangladesh would be setting an example for other countries, throughout the world, who do nothing to insure victims of climate change. Thus, besides being known as a minimal contributor to climate change, Bangladesh would also be a leader in terms of climate change adaptation efforts, more specifically climate change insurance.

In addition to extending flood insurance to the coasts, reinstating government funding for climate change adaptation efforts, such as improving infrastructure, would show other countries that the Bangladeshi government does indeed take care of its citizens. And, by providing vulnerable coastal families with an opportunity to be heard in court, Bangladesh could show the world that they are taking measures to ensure that their citizens most impacted by climate change are still afforded human rights protections and are able to voice their opinions in a court of law.

Even though these measures require a substantial amount of funding, Bangladesh can still reap a reward while remaining in compliance with their Constitution, national laws, and international human rights guarantees. By improving the living conditions and situations of impoverished coastal families, there is a chance that these families will be able to overcome poverty and contribute toward the economic viability of the country. This improvement may be the turning point in the sustenance of Bangladesh as a nation, and could expedite the country's economic growth.

234 Panos Pictures, “After the floods - Daily life in coastal Bangladesh" (Vimeo video) (6 January 2011) <http://vimeo.com/18499713> accessed 30 July 2015.

235 Costas Christ, “As the World sinks" < http://travel.nationalgeographic.com/ travel/traveler-magazine/tales-from-the-frontier/maldives/> accessed $30 \mathrm{July}$ 2015. 